\title{
UJI AKTIVITAS ANTIMIKROBA EKSTRAK RUMPUT MUTIARA (Hedyotis corimbosa (L.) Lamk) TERHADAP Escherichia coli ATCC 25922, Staphylococcus aureus ATCC 25923 dan Candida albicans ATCC 10231
}

\author{
Ema Ratna Sari, Nilda Leli, Riza Amalia \\ Sekolah Tinggi Ilmu Farmasi Bhakti Pertiwi Palembang \\ E-mail korespondensi:ema_ratnasari3@yahoo.co.id
}

\begin{abstract}
Abstrak
Telah dilakukan penelitian uji aktivitas antimikroba dari ekstrak rumput mutiara (Hedyotis corimbosa (L.) Lamk.) terhadap mikroba Escherichia coli ATCC 25922, Staphylococcus aureus ATCC 25923 dan jamur Candida albicans ATCC 10231. Metode ekstraksi yang digunakan adalah maserasi. Dari 250 gram sampel segar di peroleh rendemen sebesar 3,412\% b/b. Pengujian aktivitas antimikroba menggunakan metode difusi agar terhadap mikroba uji. Konsentrasi yang digunakan untuk uji aktivitas adalah 50\%, 30\%, dan 10\%, dengan kontrol positif kloramfenikol 0,01\% untuk bakteri dan nistatin $0,01 \%$ untuk jamur. Hasil pengamatan uji aktivitas antimikroba ekstrak kental etanol rumput mutiara ( $H$. corimbosa (L.) Lamk) menunjukkan bahwa zona hambat terbesar ada pada konsentrasi 50 $\%$ dengan rata-rata diameter hambat mikroba masing-masing sebesar $12,8 \mathrm{~mm}$ pada bakteri $E$. coli, $12,4 \mathrm{~mm}$ pada bakteri $S$. aureus dan $16,9 \mathrm{~mm}$ pada jamur C. albicans. Disimpulkan bahwa ekstrak etanol rumput mutiara (H. corimbosa (L.) Lamk.) berpotensi dikembangkan sebagai antimikroba.
\end{abstract}

Kata kunci: rumput mutiara (Hedyotis corimbosa (L.) Lamk., antimikroba, difusi agar

\section{Abstract}

An experimental antimicrobial activity test of pearl grass extract (Hedyotis corimbosa (L.) Lamk.) was performed on Escherichia coli ATCC 25922 microbe, Staphylococcus aureus ATCC 25923 and Candida albicans ATCC 10231 fungus. The method of extraction used was maceration. The yield obtained from 250 grams of fresh samples was $3.412 \% \mathrm{w} / \mathrm{w}$. Testing of antimicrobial activity was carried out using agar diffusion method. The concentrations used for the activity test were $50 \%, 30 \%$, and $10 \%$, with $0.01 \%$ positive chloramphenicol control for bacteria and $0.01 \%$ nystatin for the fungus. The result showed that the largest inhibition zone was at concentration 50\% with mean of microbial inhibitory diameter respectively $12.8 \mathrm{~mm}$ in E. coli, $12.4 \mathrm{~mm}$ in S. aureus, and $16.9 \mathrm{~mm}$ in C. albicans. In conclusion, pearl grass ethanolic extract (H. corimbosa (L.) Lamk.) is potential to be developed as antimicrobial agent.

Keywords: pearl grass (Hedyotis corimbosa (L.) Lamk, antimicrobial, agar diffusion method

\section{PENDAHULUAN}

Jenis antimikroba telah tersedia untuk mengobati penyakit yang disebabkan oleh mikroorganisme. Antimikroba merupakan zat yang bertujuan untuk mengeliminasi infeksi mikroorganisme atau mencegah terjadinya infeksi. Untuk tujuan terapi, suatu zat antimikroba harus menunjukkan toksisitas selektif. Zat antimikroba yang berguna untuk terapi harus menghambat mikroorganisme infektif, zat antimikroba yang paling banyak digunakan dalam pengobatan adalah yang mempengaruhi kerja dengan menghambat atau membunuh mikroorganisme patogen (Harmita dkk, 2008).

Penelitian antimikroba telah banyak dilakukan, namun para ilmuwan terus berusaha untuk mencari sumber antimikroba baru, terutama yang mudah tumbuh di Indonesia. Tumbuhan yang digunakan untuk obat tradisional dapat dijadikan alternatif pencarian zat antimikroba, karena pada umumnya memiliki senyawa aktif yang sangat berperan dalam bidang kesehatan (Ervizal dkk, 2001).

Salah satu tanaman yang digunakan adalah rumput mutiara yang merupakan tanaman herbal yang dapat berkhasiat sebagai obat. Rumput mutiara memiliki kandungan senyawa asam oleanolat dan asam ursolat yang dapat mencegah perkembangan sel kanker. Kandungan kimia lainnya yg dimiliki rumput mutiara seperti hentiacontane, stigmasterol, asam ursalat,oleanolic acid , $\beta$ - sitosterol, sitosterol-Dglucoside,p-coumoric acid dan flavanoit glikosid (Ina, 2015). Manfaat lain rumput mutiara adalah sebagai antipiretik, antiradang, antibakteri, deuretik, detoksikan (menghilangkan panas dan racun), melancarkan sirkulasi darah, dan antikanker (Hariana, 2008).

Hasil penelitian menunjukan bahwa dalam ekstrak rumput mutiara terdapat zat aktif yang berfungsi sebagai antibakteri yang terdapat dalam fraksi metilen klorida, pada fraksi ini aktivitas paling baik dihasilkan oleh bakteri Shigella disentry dengan diameter daerah hambatan sebesar 27,5 mm (Mukmilah dkk, 2012). Maka dari uraian diatas, peneliti tertarik untuk menguji aktivitas antimikroba dari ekstrak rumput mutiara (Hedyotis corimbosa (L.) Lamk).

\section{METODE}

Alat

Seperangkat alat maserasi, destilasi vakum, rotary evaporator, beaker glass, pipet tetes, cawan petri, lumpang, mortir, timbangan, gelas ukur, pinset, erlemeyer, jarum ose, autoklaf, inkubator, Laminar Air Flow.

\section{Bahan}

Rumput mutiara, media nutrient agar dan potato dekstro agar, aquadest steril, etanol $96 \%$,etanol 
destilasi, $\mathrm{NaCl}$ fisiologis, biakan bakteri Staphylococcus aureus ATCC 25923 dan bakteri Escherichia coli ATCC 25922 serta biakan jamur Candida albicans ATCC 10231 kertas cakram, kapas, kasa steril, tali, kertas saring, serta aluminium foil.

\section{Uji Pendahuluan Kandungan Kimia Rumput Mutiara (H. corimbosa (L.) Lamk)}

Identifikasi senyawa alkaloid menggunakan metode Culvenor Fitzgerald dan identifikasi senyawa flavonoid, fenolik, saponin, terpenoid dan steroid menggunakan metoda Simes dkk, yang dimodifikasi.

\section{Ekstraksi}

Rumput mutiara segar dibersihkan, dirajang dan ditimbang sebanyak $2 \mathrm{~kg}$. Lalu diekstraksi dengan cara maserasi. Proses maserasi dilakukan 3 kali perendaman selama 5 hari kemudian disaring sehingga didapat maseratnya. Maserat diuapkan pelarutnya menggunakan destilasi vakum dan rotary evaporator sampai didapat ekstrak kental.

\section{Sterilisasi Alat dan Bahan}

Alat-alat gelas disterilkan dalam autoklaf pada suhu $121^{\circ} \mathrm{C}$ dengan tekanan $15 \mathrm{lbs}$ selama 15 menit. Pinset, jarum ose dan kaca objek disterilkan dengan cara pemijaran dengan jalan melewatkan pada nyala api selama 20 detik (Dwidjoseputro, 1998). LAF disterilkan dengan cara dibersihkan dari debu lalu disemprot dengan alkohol 70\%, lampu UV dinyalakan selama 10 menit.

\section{Pembuatan Larutan Uji dan Kontrol}

Konsentrasi yang dibuat yaitu 10\%, 30\% dan $50 \%$ b/v dengan pelarut etanol destilat. Larutan kontrol positif (+) yaitu kloramfenikol dan nistatin dibuat dengan konsentrasi $0,01 \%$ b/v. Larutan kontrol negatif (-) yang digunakan etanol destilat.

\section{Uji Penghambatan Pertumbuhan Bakteri}

Sebanyak 0,1 $\mathrm{ml}$ suspensi bakteri diteteskan ke dalam tabung reaksi yang berisi $10 \mathrm{ml}$ media agar, dihomogenkan kemudian dituangkan di atas cawan petri yang berisi $10 \mathrm{ml}$ media agar yang telah memadat. Cawan petri tersebut digoyangkan beberapa kali secara horizontal agar suspensi bakteri merata pada seluruh permukaan agar. Kemudian dibiarkan pada suhu kamar selama 15 menit. Setiap bakteri uji ditempatkan pada 3 cawan petri untuk tiap larutan uji dan pengujian dilakukan sebanyak tiga kali (Cappuccino, 2009). Cakram kertas yang telah disterilkan dicelupkan ke dalam masing- masing konsentrasi zat uji yang telah disiapkan kemudian diletakkan pada permukaan media agar yang telah diinokulasi dengan bakteri. Cawan petri yang berisi agar inokulum diinkubasi kedalam inkubator pada suhu 37 으 selama 48 jam. Kemudian diukur diameter zona bening yang terbentuk dengan menggunakan jangka sorong (Harmita \& Radji, 2008).

\section{HASIL DAN PEMBAHASAN}

Pada penelitian ini dilakukan terlebih dahulu uji pendahuluan fitokimia dengan metode Culvenor \& Fritzgerald dan Simes,dkk, dan diperoleh kandungan kimianya adalah senyawa flavonoid, fenolik dan steroid. Metode ekstraksi yang digunakan adalah maserasi. Maserasi merupakan metode ekstraksi yang cocok digunakan untuk mengekstraksi sampel yang tidak tahan pemanasan (termolabil), sehingga kemungkinan hilangnya kandungan kimia didalam tanaman yang rusak akibat pemanasan dapat dihindari. (Harborne, 1987). Kemudian maserat diuapkan pelarutnya menggunakan destilasi vakum, dan rotary evaporator, sehingga diperoleh ekstrak kental rumput mutiara sebesar 8,53 g (Rendemennya sebesar 3,412\% b/b).

Pada uji aktivitas ekstrak rumput mutiara $(H$. corimbosa L.) digunakan konsentrasi mulai dari $10 \%$ $\mathrm{b} / \mathrm{v}, 30 \% \mathrm{~b} / \mathrm{v}$, dan $50 \% \mathrm{~b} / \mathrm{v}$, dengan kontrol positif kloramfenikol 0,01\% untuk uji pada bakteri dan nistatin 0,01\% untuk uji pada jamur sedangkan kontrol negatif digunakan etanol destilasi. Digunakan kloramfenikol karena mekanisme kerjanya berdasarkan perintangan sintesa polipeptida kuman. Kloramfenikol juga merupakan antibiotikum broadspectrum yang berkhasiat bakteriostatis terhadap hampir semua kuman Gram-positif dan sejumlah kuman Gram-negatif, juga terhadap spirocharta dan Mycoplasma. Bekerja bakterisid terhadap Str. Pneumonia, Neiss. Meningitides dan $H$. influenza. Digunakan nistatin karena nistatin memiliki struktur dan mekanisme kerja yang sama dengan Amphotericin $B$ yaitu berinteraksi dengan ergosterol pada membran sel dan nistatin juga hanya untuk indikasi kandidiasis (Tjay dkk, 2007).

Metode yang digunakan dalam uji aktivitas antimikroba adalah metode difusi agar dimana metode ini berprinsip zat yang akan diuji berdifusi dari pencadang (reservoir) ke dalam medium agar yang telah diinokulasi dengan mikroba uji. Inkubasi selama waktu tertentu dan kemudian diamati adanya hambatan pertumbuhan mikroba uji dan diukur diameter hambatannya. Metode penetapan Potensi dengan cara sederhana dan hasil yang diperoleh cukup teliti (Farmakope Indonesia IV , 1995). Diameter hambat uji aktivitas ekstrak etanol rumput mutiara terhadap bakteri $E$. coli terlihat pada Gambar 1 . 


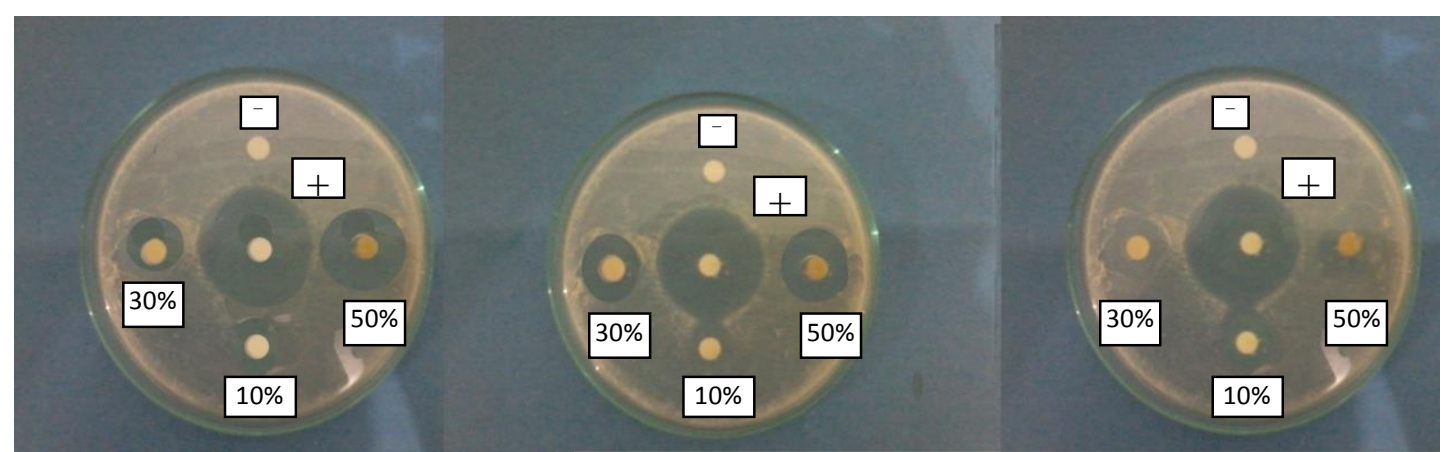

Gambar 1. Diameter Hambat Ekstrak Rumput Mutiara Terhadap Bakteri E. coli

Tabel 1. Diameter Hambat Ekstrak Rumput Mutiara Terhadap Bakteri E. coli

\begin{tabular}{|c|c|c|c|c|}
\hline \multirow{2}{*}{ Konsentrasi } & Zona Hambat & Zona Hambat & Zona Hambat & \multirow{2}{*}{ Rata-Rata } \\
\cline { 2 - 4 } & $\mathbf{1}$ & $\mathbf{2}$ & $\mathbf{3}$ & \\
\hline $\mathrm{K}(-)$ & - & - & - & - \\
\hline $\mathrm{K}(+)$ & $19,5 \mathrm{~mm}$ & $18,3 \mathrm{~mm}$ & $18,7 \mathrm{~mm}$ & $18,8 \mathrm{~mm}$ \\
\hline $50 \%$ & $15,4 \mathrm{~mm}$ & $12,6 \mathrm{~mm}$ & $10,4 \mathrm{~mm}$ & $12,8 \mathrm{~mm}$ \\
\hline $30 \%$ & $8,8 \mathrm{~mm}$ & $9,2 \mathrm{~mm}$ & $8,2 \mathrm{~mm}$ & $8,7 \mathrm{~mm}$ \\
\hline $10 \%$ & $6,8 \mathrm{~mm}$ & $7,5 \mathrm{~mm}$ & $7,6 \mathrm{~mm}$ & $7,3 \mathrm{~mm}$ \\
\hline
\end{tabular}

Diameter hambat uji aktivitas ekstrak etanol rumput mutiara terhadap bakteri S. aureus terlihat pada Gambar 2.

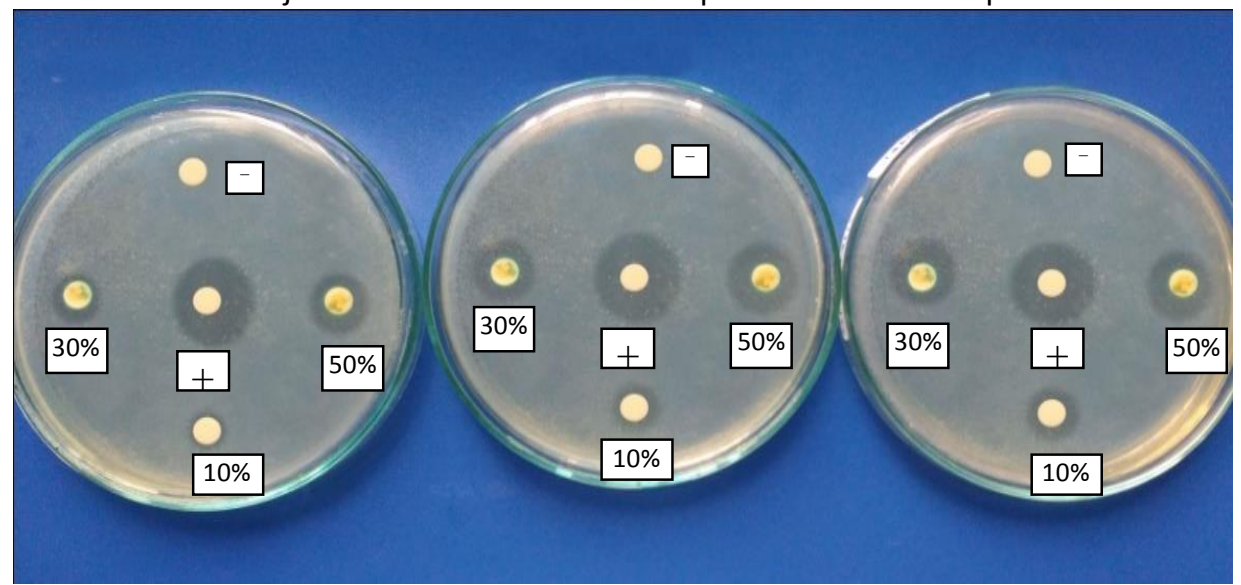

Gambar 2. Diameter Hambat Ekstrak Rumput Mutiara Terhadap Bakteri S. aureus

Tabel.2 Diameter Hambat Ekstrak Rumput Mutiara Terhadap Bakteri S. aureus

\begin{tabular}{|c|c|c|c|c|}
\hline \multirow{2}{*}{ Konsentrasi } & Zona Hambat & Zona Hambat & Zona Hambat & \multirow{2}{*}{ Rata-Rata } \\
\cline { 2 - 4 } & $\mathbf{1}$ & $\mathbf{2}$ & $\mathbf{3}$ & - \\
\hline $\mathrm{K}(-)$ & - & - & - & $14,4 \mathrm{~mm}$ \\
\hline $\mathrm{K}(+)$ & $14,3 \mathrm{~mm}$ & $15,2 \mathrm{~mm}$ & $13,8 \mathrm{~mm}$ & $12,4 \mathrm{~mm}$ \\
\hline $50 \%$ & $10,7 \mathrm{~mm}$ & $13,3 \mathrm{~mm}$ & $13,2 \mathrm{~mm}$ & $8,2 \mathrm{~mm}$ \\
\hline $30 \%$ & $7,4 \mathrm{~mm}$ & $8,5 \mathrm{~mm}$ & $8,6 \mathrm{~mm}$ & $6,4 \mathrm{~mm}$ \\
\hline $10 \%$ & $6,2 \mathrm{~mm}$ & $6,4 \mathrm{~mm}$ & $6,7 \mathrm{~mm}$ & \\
\hline
\end{tabular}

Diameter hambat uji aktivitas ekstrak etanol rumput mutiara terhadap jamur C. albicans terlihat pada Gambar 3. 


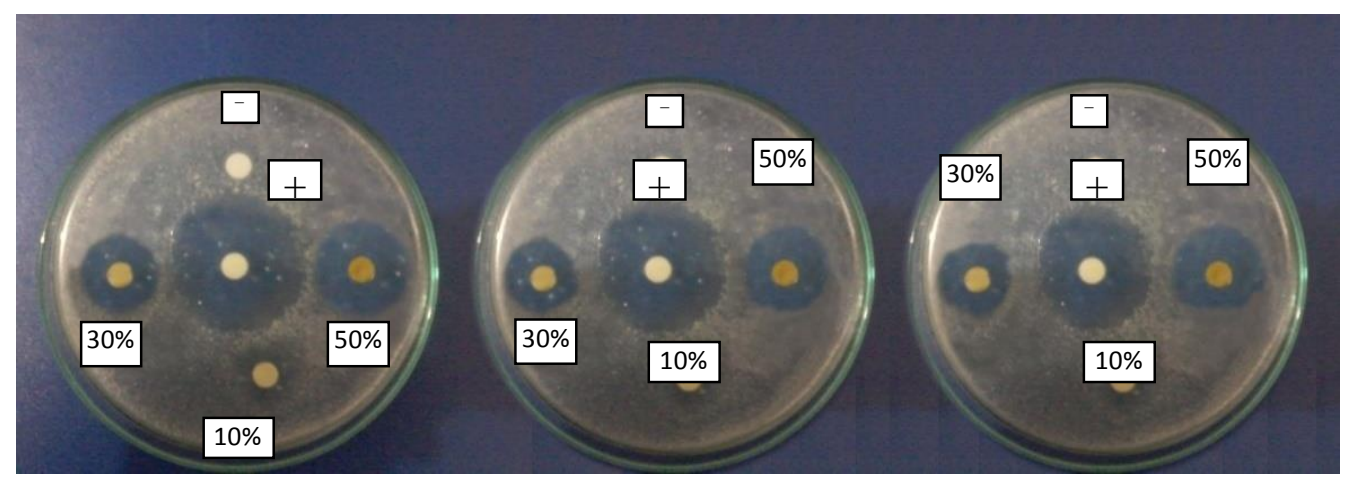

Gambar 3. Diameter Hambat Ekstrak Rumput Mutiara Terhadap Jamur C. albicans.

Tabel.3 Diameter Hambat Ekstrak Rumput Mutiara Terhadap Jamur C. albicans.

\begin{tabular}{|c|c|c|c|c|}
\hline \multirow{2}{*}{ Konsentrasi } & $\begin{array}{c}\text { Zona } \\
\text { Hambat }\end{array}$ & Zona Hambat & Zona Hambat & \multirow{2}{*}{ Rata-Rata } \\
\cline { 2 - 4 } & $\mathbf{1}$ & $\mathbf{2}$ & $\mathbf{3}$ & \multicolumn{1}{|c}{} \\
\hline $\mathrm{K}(-)$ & - & - & - & $18,1 \mathrm{~mm}$ \\
\hline $\mathrm{K}(+)$ & $18,2 \mathrm{~mm}$ & $18,8 \mathrm{~mm}$ & $17,4 \mathrm{~mm}$ & $16,9 \mathrm{~mm}$ \\
\hline $50 \%$ & $17,4 \mathrm{~mm}$ & $16,3 \mathrm{~mm}$ & $17,1 \mathrm{~mm}$ & $9,1 \mathrm{~mm}$ \\
\hline $30 \%$ & $10,5 \mathrm{~mm}$ & $8,2 \mathrm{~mm}$ & $8,5 \mathrm{~mm}$ & $6,9 \mathrm{~mm}$ \\
\hline $10 \%$ & $7,2 \mathrm{~mm}$ & $6,8 \mathrm{~mm}$ & $6,6 \mathrm{~mm}$ & \\
\hline
\end{tabular}

Pada pengujian diatas diketahui bahwa ekstrak yang di ujikan pada bakteri $E$. coli, S. aureus, dan jamur $C$. albicans pada konsentrasi $50 \%$ masing-masing menunjukkan daerah hambat yang lebih besar, ini disebabkan oleh aktivitas ekstrak rumput mutiara terhadap bakteri dan jamur. Ternyata dari kedua bakteri pada konsentrasi 50\% memiliki daerah hambat yang kurang lebih sama yaitu $12,8 \mathrm{~mm}$ pada bakteri $E$. coli dan $12,4 \mathrm{~mm}$ pada bakteri $S$. aureus. Sedangkan pada jamur $C$. albicans daerah hambat yang dimiliki ternyata lebih besar yaitu $16,9 \mathrm{~mm}$. Dari penelitian ini dapat dlihat juga bahwa kontrol positif memiliki aktivitas daya hambat yang lebih besar dibandingkan konsentrasi $50 \%$ ini dilihat dari mekanisme kerja obat yang digunakan pada kontrol positif. Berdasarkan uraian diatas, membuktikan bahwa rumput mutiara ( Hedyotis corimbosa L.) mempunyai aktivitas antimikroba terhadap bakteri E. coli ATCC 25922, bakteri S. aureus ATCC 25923 dan jamur C. albicans ATCC 10231.

\section{SIMPULAN}

Ekstrak etanol rumput mutiara (Hedyotis corimbosa L.) berpotensi untuk dikembangkan sebagai antimikroba terhadap bakteri E. coli, bakteri S. aureus, dan jamur C. albicans.

\section{UCAPAN TERIMA KASIH}

Almamater STIFI Bhakti Pertiwi Palembang

\section{DAFTAR PUSTAKA}

Alex, C.S, W \& L, Jarets, 1980, Grod whol's Clinical laboratory methods and diagnosis. (volume 2) CV . Mosby campany ST. Louis Toronto London, 13911407.

Dalimartha, 2008. Atlas Tumbuhan Obat Indonesia Jilid 5. Jakarta Pustaka.

Departemen Kesehatan RI, 1995. Farmakope Indonesia Edisi IV. Dirjen POM. jakarta Indonesia.

Dwidjoseputro, D,. 1998. Dasar-dasar Mikrobiologi. Djambatan. Jakarta Indonesia.

Ervizal, Winiati, Hanny dan Pipi, 2001. Aktivitas Antimikroba Ekstrak Kedawung Terhadap Bakteri

Patogen.www.scribd.com/doc/51850979/JurnalAktifitas-Anti- Mikroba- Terhadap-BakteriPatogen. Diakses tanggal 17 maret 2016.

Hadioetomo, RS, 1995. Mikrobiologi Dasar dalam Praktek. Jakarta: Gramedia.

Harmita,dan Maksum, 2008, Buku Ajar Analisis Hayati Ed 3. Penerbit Buku Kedokteran.EGC. Jakarta.

Hariana, 2008. Tumbuhan Obat \& Khasiatnya 3. Niaga Swadaya. Jakarta Indonesia.

Inayulia, 2015. Jurnal Rumput Mutiara. www. Scribd.com/doc/292839792 jurnal-rumputmutiara. Diakses tanggal 17 maret 2016.

Jawetz, E. Melnick, J. dan E. Adelberg, 1989, Mikrobiologi Untuk Propesi Kesehatan ( edisi 14 ) diterjemahkan G. Bonang, ECG Buku Kedokteran, Jakarta 256-428. 
Lay, BW., 1994, Analisa Mikroorganisme di Laboratorium, Raja Grafindo Perkasa, Jakarta.

Machmud, M, 2001. Teknik Penyimpanan dan Pemeliharaan Mikroba. Bogor: Balai Penelitian Bioteknologi Tanaman Pangan.

Mukmilah, Zalinar dan Elis,2012. Uji Aktivitas Antibakteri Dari Ekstrak Rumput Mutiara (Hedyotis corymbosa (L.)Lamk), volume 2. Journal.uinjkt.ac.id. Diakses tanggal 18 agustus 2016.

Seputro, DD., 1998, Dasar-dasar Mikrobiologi, Djamal, Jakarta, hal. 2-20
Suriawira, U., 1995, Pengantar Mikrobiologi Umum, Angkasa, Bandung, 65-78

Syahrurachman, A., 1994, Mikrobiologi Kedokteran, FK Universitas Indonesia, Jakarta.

Tjay, H., dan Kirana, 2007, Obat-obat Penting Khasiat, Penggunaan dan Efek-efek Sampingnya, Edisi VI, PT Alex Media Komputindo, Jakarta.

Volk, W.A., dan M.F Wheeler, 1990, Mikrobiologi Dasar, Edisi V, diterjemahkan Oleh Adisumartono.S, Erlangga, Jakarta 6-67 